\title{
How Corporate Governance affect Firm Value and profitability? Evidence from Saudi Financial and Non-Financial Listed Firms
}

(Short title: Corporate Governance and Firm Value in Saudi Arabia)

\author{
Ali M. Gerged* \\ (Corresponding author) \\ Leicester Castle Business School \\ De Montfort University \\ The Gateway, Leicester, LE1 9BH, UK \\ ali.gerged@dmu.ac.uk \\ Faculty of Economics \\ Misurata University \\ Misurata City \\ PO Box 2478, Libya
}

\author{
Ahmed Agwili \\ Huddersfield Business School \\ University of Huddersfield \\ Queensgate \\ Huddersfield HD1 3DH \\ United Kingdom \\ aagwili@yahoo.com
}

This paper cited as:

Gerged, A., and Agwili, A. (2019). 'How Corporate Governance affect Firm Value and profitability? Evidence from Saudi Financial and Non-Financial Listed Firms'. International Journal of Business Governance and Ethics. (In Press). 


\title{
How Corporate Governance affect Firm Value and profitability? Evidence from Saudi Financial and Non-Financial Listed Firms
}

\begin{abstract}
:
This paper investigates the possible effects of corporate governance (CG) mechanisms on the firm market and accounting value (FV) in Saudi Arabia after the 2011 CG reforms using a sample of 300 annual reports of financial and non-financial companies listed on Tadawul from 2012 to 2016. Our results are suggestive of heterogeneous effects of CG mechanisms on firm value and profitability in that they might have either encouraged or discouraged FV in Saudi Arabia. This means that, averagely, better-governed firms tend to achieve better market value, but not necessarily a better accounting value. Our findings indicate that implementing a voluntary 'comply-or-explain' CG regime in Saudi Arabia has, so far, a limited impact on FV. This implies that developing other enforcement mechanisms for CG provisions, such as appending good CG practices to listing rules for companies to comply with, might lead to better financial results for those well-governed companies in Saudi Arabia. Despite the limitations, it is hoped that our study can inspire further examinations in this research area.
\end{abstract}

\section{Key Words}

Corporate Governance, Firm Value, Panel Data, Profitability, Saudi Arabia, Tadawul.

\section{Introduction}

Corporate governance (CG) has received considerable attention due to a series of scandals and corporate failures that seemed to be attributed to the implementation of different accounting and disclosure practices (Anghel \& Man, 2014). The recent financial crises have also led to more attention being devoted to CG practices and research internationally (Boubaker \& Nguyen, 2014). CG is defined as the system under which a company is managed and controlled, by organising relations between the board of directors, executive managers, shareholders and other stakeholders (Belkhir, 2009). The concept of CG has been defined from different perspectives, such as regulators, investors and shareholders because it covers different economic aspects. Although there is a noted variation in the definitions of CG, there is a general consensus on the enormous benefits of good CG practices at micro and macro levels in the form of stimulating inwards foreign direct investment (FDI), operational efficiency, and increasing firm valuation in the long-term (Roberta, et al, 2008). Despite some benefits that companies could gain by being complied with fair CG, there is no "all-fits- 
all" CG model, and each state ought to integrate the principles of CG and procedures to which best fit within the political, economic and social characteristics of its context (Roberta et al., 2008).

CG mechanisms classified into two main categories are the internal mechanisms such as board characteristics and external mechanisms such as competitive market conditions (Yusoff \& Alhaji, 2012; Zabria, 2015). Well-designed board characteristics are believed to be effective mechanisms in governing companies' behaviour within a given country (Elsayed, 2011). Unethical behaviours committed by companies are negatively affecting the sustainability of stock markets, and leading to the failure of multi-national companies such as Enron (2001) and WorldCom (2002) (Choo, 2008). High-level CG compliance, on the other hand, is assumed to enhance the firm value that might result in maximising shareholders' returns and reducing the conflict of interests between managers and shareholders (Yusoff \& Alhaji, 2012). Accordingly, the importance of compliance with CG provisions has been addressed through several previous studies internationally.

Agency theory advances our understanding about how can effective CG internal mechanisms reduce agency costs and mitigate agency problems, thereby resulting in enhancing corporate compliance with CG provisions along with a better firm performance/valuation (Fama \& Jensen, 1983). For example, it suggests that CG mechanisms may be used to monitor managers' opportunistic behaviour and align their interests with those of principals (Haniffa \& Hudaib, 2006). Similarly, increasing the number of outside executives might lead to reducing agency problems by improving the effectiveness and independence of the board of directors (Fama \& Jensen, 1983). Similarly, board diversity assumed to reduce information asymmetry by monitoring management activities (Walt \& Ingley, 2003). Likewise, setting up board committees (e.g., audit committees); can reduce agency conflicts by improving boards' efficiency and effectiveness (Klein, 1998). Our study, therefore, employs agency theory to develop our hypotheses and to interpret our findings.

Previous research suggested that good CG practices may be attributed to achieving optimal levels of firm financial performance and reaching a company's goals with minimal risks (Rezaee, 2009). Although, a significant body of research investigates the expected financial benefits of corporate compliance with good CG practices in both developed and developing countries (See Ammann et al., 2011; Brown and Caylor, 2006; Chhaochharia and Grinstein, 2007; Jo and Harjoto, 2011), a few researchers (see Abdallah and Ismail, 2017; Buallay et al., 2017) have focused on examining the association between CG and FV in Saudi Arabia. 
However, these existing research studies have employed different CG mechanisms and investigated the impact of CG disclosure rather than compliance on FV in Saudi Arabia. The current study, therefore, seeks to extend present knowledge by providing several contributions to the literature of CG in emerging economies. First, we offer new evidence on the voluntary compliance with good CG practices among listed firms in Saudi Arabia following the pursuance of the 2011 CG reforms. Thus, our study contributes to the CG literature by providing empirical evidence on the extent to which the current Saudi CG code has helped in enhancing CG standards in listed companies. Second, our study is distinguished from prior studies (see Abdallah and Ismail, 2017; Buallay et al., 2017) by examining the value relevance of voluntary compliance with different CG variables such as audit committees' characteristics. Arguably, the effectiveness of audit committees appeared to be resulting in preventing inter-agency conflicts and improving FV (Bouaziz, 2012). Third, we examine the impact of CG participation rather than disclosure on FV. Finally, the Saudi stock market has witnessed transformative changes after 2011, such as the implementation of the UK voluntary CG style 'comply-or-explain'. Thus, our study examines the CG-FV nexus from 2012 to 2016.

The kingdom of Saudi Arabia is a G20 member and is considered the largest oil and gas producer in the world (Abraham et al., 2001). As a result of the reformation of the Saudi economy such as improving credit risk, privatisation and attracting FDI, the gross domestic product (GDP) has grown from the US \$ 528.2 in 2010 to the US \$ 756.4 billion in 2014 (Mezghani and Haddad, 2017). Saudi Arabia has the largest stock exchange (called Tadawul) in the Gulf Cooperation Council (GCC) region, which was established in the mid-1930 (Lee, 2006). The market capitalisation of Tadawul is US $\$ 202.5$ billion at December 31, 2010, and ranked in terms of size as the $23^{\text {rd }}$ globally (Fallatah and Dickins, 2012). Also, the Saudi stock exchange has experienced substantial growth in the number of listed companies from 86 in 2006 to 175 in 2016 (Trading, 2017).

The history of CG in Saudi Arabia can be traced back to 1965 when companies operating in the country were required to prepare and audit their financial statements by certified chartered accountants. Many of these firms, however, have failed to publish their financial statements, which resulted in losing Tadawul to about $50 \%$ of its market capitalisation in 2006 (Yaser \& Denise, 2012). Subsequently, further regulations were required to address the deterioration of investors' confidence in Tadawul. The Capital Market Authority (CMA), therefore, developed the Saudi Code of Corporate Governance (CCG) in 2006 (CMA, 2007). 
Although CG practices are still considered to be at an early stage in Saudi Arabia compared to its developed counterparts, there were several attempts to reform and improve CG system in the country (AL-Kahtani, 2013). For example, from the beginning of 2011, Saudi listed firms are required to be compliant with the CG code on a 'comply-or-explain' basis following the UK CG regime (CMA, 2011). Based on the 'comply or explain' regime, Saudi companies should clearly state their compliance and/or non-compliance with the provisions of CG code in the report of the board of directors and any other available format (Al-Habshan, 2015).

Given the consequences of non-compliance with CG code that have led to violating companies' value and Tadawul's market capitalisation in Saudi Arabia, this study seeks to investigate the expected financial consequences of compliance with CG provisions in Saudi Arabia after adopting the voluntary system of CG in 2011 using a sample of 300 annual reports of financial and non-financial companies listed on Tadawul from 2012 to 2016. Specifically, we investigate the efficiency and effectiveness of the voluntary nature of ‘comply-or-explain’ CG compliance regime in Saudi Arabia post-2011.

The next section reviews previous governance-to-value studies to identify the existing gap in the literature.

\section{Literature review and hypothesis development:}

In our review of governance-to-vale studies, we devote our attention to emerging markets that experience various governance issues compared to mature markets (Bebchuk and Hamdani, 2008). A body of previous research focused on examining whether a measure of CG can predict firm market value (proxied by Tobin's q) and accounting value (proxied usually by return on assets (ROA) and/or return on equity (ROE)) (See Black et al., 2014; Claessens and Yurtoglu, 2013).

We can divide our review into cross-country studies and single-country studies. The primary cross-country studies which included some emerging markets are Black et al. (2014), Durnev and Kim (2005), Dahya et al. (2008), Grassa and Matoussi (2014), Quttainah et al. (2017), and Klapper and Love (2004). Similarly, there are various single-country studies conducted on emerging markets such as India (e.g., Balasubramanian et al., 2010; Sarkar and Saekar, 2012); Brazil (e.g., Black et al., 2012; Braga-Alves \& Shastri, 2011; Leal \& Carvalhal da Silva, 2007); Thailand (Limpaphayom and Connelly, 2004; Kouwenberg, 2006); South Africa (e.g., Ntim, 2013); and Russia (e.g., Black, 2001; Kuznecovs \& Pal, 2012). However, most of these studies lack time-series data on CG and most used limited covariates. Findings 
with limited covariates might be weakened with more relevant covariates (Black et al., 2014). Likewise, findings obtained from cross-sectional data may be weakened or disappeared if panel data has been considered, particularly in which related to governance-to-value investigations (Ararat et al., 2017). In our study, therefore, we examine the CG-FV nexus in Saudi Arabia employing panel data that combines both cross-sectional data (financial and non-financial sectors) and time-series data (2012 to 2016) in order to produce rigorous and reliable results.

Regarding governance-to-value studies in the Middle East and North Africa (MENA) region, including Saudi Arabia, there is a little attention being paid to examining this relationship. For example, Al-Haddad et al. (2011) examine the relationship between CG and firm financial performance (proxied by ROA and ROE) using a sample of 44 Jordanian listed firms. The study indicates that CG is attributed to financial performance in Jordan. Similarly, Elsayed (2011) studied the impact of board size on financial performance using a sample of 92 listed firms in Egypt. This study suggests that CG can predict firm financial performance. Likewise, Najjar (2012) confirms no statistical impact of CG on firms’ financial performance in Bahrain, although Ahmed and Hamdan (2015) suggest an inverse relationship after implementing the 2011 CG reforms in Bahrain. All these studies have focused on examining the relationship between CG and firm financial value (measured mainly by ROA and ROE) rather than market value (proxied usually by Tobin’s q). Additionally, Salloum et al. (2013) concluded that the existence of outside directors and CEO duality appeared to have no impact on banks performance in Lebanon.

The closest studies to our investigation are Al-Sahafi et al. (2015); Al-Ghamdi and Rhodes (2015); Abdallah and Ismail (2017); and Buallay et al. (2017). While Al-Sahafi et al. (2015) investigate the CG-financial performance connexion among listed banks in Saudi Arabia, AlGhamdi and Rhodes, (2015) focused on governance-to-financial performance examination among Saudi non-financial listed companies. Crucially, neither Al-Sahafi et al. (2015) nor Al-Ghamdi and Rhodes (2015) has examined the CG-FV nexus employing Tobin's q as a proxy for FV. Also, there was limited coverage of sectors by both studies. Sahafi et al. (2015) was a single-sector study focusing mainly on the banking sector, while Al-Ghamdi and Rhodes (2015) were inclusive of non-financial companies, only. Even though Abdallah and Ismail (2017) focused on examining the relationship between CG disclosure, ownership structure, and corporate performance in the GCC countries, including a more significant 
number of Saudi firms, this study is however limited to Thomson and Reuters Zawya dataset and DataStream. Crucially, Abdallah and Ismail (2017) use the Behavioural Assessment Score for Investors and Corporations (BASIC) as a proxy for CG, which consists of three main categories, are trading history, corporate communication, and disclosure. The only category that included CG items is the disclosure category. These items are restricted to board sub-committees, director independence, and executive/non-executive directors. These items (parameters), furthermore, are calculated based on a dichotomous process where an item is given one if it is disclosed and zero otherwise. This implies that Abdallah and Ismail (2017) was limited to examining the association between CG disclosure, rather than CG compliance, and corporate performance. Additionally, their analysis was confined to the period from 2008 to 2012. Our study, therefore, addresses these gaps as follows.

First, we use a self-constructed dataset as a proxy for CG. Our data is manually collected from the corporate annual report that is associative of high-level credibility and reliability (Deegan and Rankin, 1997) as compared with existing datasets (Gerged et al., 2018). In this regard, Epstein and Freedman (1994) argue that corporate annual reports remain the primary means of systematic accountability to all user groups and influential stakeholders. It further contends that the annual report is an essential means of corporate communication with a relatively large degree of reliability and credibility. Second, our study focuses on exploring the possible effects of corporate compliance with the provisions of CG code in Saudi Arabia on firm value as opposed to Abdallah and Ismail (2017) that studied the impact of CG disclosure on FV. In our study, we employ different CG internal mechanisms (i.e., board structure and audit committee characteristics) to Abdallah and Ismail (2017) that use broader CG disclosure items calculated on a binary basis. Third, the period of our investigation (i.e., 2012 to 2016) is much more updated than Abdallah and Ismail (2017) that was limited to the period from 2008 to 2012. Given the recent CG reforms and institutional changes in Saudi Arabia such as the implementation of the 'comply-or-explain' CG regime in 2011, our study exclusively examines the impact of these CG reforms on FV in the context of the study.

Although Buallay et al. (2017) were confined to three years from 2012 to 2014, our study covers a longer (i.e., five years) and a more updated period spans from 2012 to 2016. In addition, we do examine different CG internal mechanism (i.e., board structure and audit committee characteristics) as compared to Buallay et al. (2017) that was restricted to board structures. 
Drawing on previous literature, we address these existing gaps in CG literature in emerging markets by investigating how can the voluntary compliance with CG provisions affect both firm market and accounting values using various CG mechanisms and a sample of financial and non-financial Saudi listed firms after the implementation of the new CG regime (i.e., comply or explain) of 2011 in Saudi Arabia.

The implementation of good CG can ensure that companies' assets are well managed by agents, which eliminates any conflict of interests and agency fees (Belkhir, 2009). Ross (1973) first introduced agency problems, while the first detailed theoretical presentation of agency theory was by Jensen and Meckling (1976), who defined the company directors as "agents" and the shareholders as the "principals". In other words, the shareholders "principal" of a company authorise the decision-making process to the members of the board of directors. The agency problem arises due to a separation between the management and ownership of business entities (Sulong and Ahmed, 2011). It is likely that corporate managers prefer to pursue their personal goals, and interests, such as increasing their pay and remunerations, instead of maximising the wealth of shareholders (Jensen and Meckling, 1976).

Agency theory states that the conflict of interests and the disparity of information can be reduced by an appropriate set of monitoring mechanisms to align the interests of different parties within a company (Haniffa and Hudaib, 2006), one of these monitoring tools is proper CG compliance (Walt \& Ingley, 2003). The most popular CG internal mechanisms are the board of directors. The efficiency and effectiveness of the board of directors may play an essential role in improving the value of the company and reducing agency disputes between shareholders and management (Klein, 1998). Similarly, an agency conflict can be linked to a moral hazard where managers may manipulate accounting figures in financial statements to increase their remuneration, for instance (Haniffa and Cooke, 2002). Audit committees can, therefore, reduce this conflict of interests by overseeing financial reports, external and internal audits (Klein, 1998). In this regard Bouaziz (2012) state that the effectiveness of board and audit committees is associated with greater control over corporate management behaviour which appeared to result in reducing the possibility of fraud, preventing interagency conflict and improving firm financial performance. 
In totalities, we argue that agency theory offers a better understanding regarding the efficiency and effectiveness of corporate compliance with CG internal mechanisms in reducing agency costs and mitigating agency conflicts, leading thereby to enhancing firm value (Fama \& Jensen, 1983). Consequently, we employ an agency theoretical framework to conceptualise the relationship between CG compliance and firm value post the adaptation of the UK ‘comply-or-explain’ CG system in Saudi Arabia in 2011.

\section{Hypotheses Development}

The board of directors is considered the primary internal mechanism of CG, as it is responsible for a company's performance on behalf of shareholders. Several factors, such as board size, directors' experience and independence, board composition and meetings, affect the effectiveness of the board of directors (Black et al., 2014). As the board of directors has the overall responsibility to monitor the performance of management and its effectiveness, it is significantly affecting a company's financial performance (See Al-Kahtani, 2013; AlSahafi et al., 2015; Al-Ghamdi and Rhodes, 2015). Arguably, board characteristics can play a significant role in reducing agency conflicts and therefore, enhancing firm value (Bouaziz, 2012). Thus, the first hypothesis to test in our study is:

H1: Board characteristics are positively and significantly associated with the firm value (proxied by Tobin's q) and profitability (proxied by ROA and ROE) among a sample of financial and non-financial firms listed on the Saudi Stock market (Tadawul) from 2012 to 2016.

This central hypothesis could be divided into the following sub-hypotheses.

Board size could be varied across countries. For instance, the board of directors in the UK tend to be smaller than ten members, although it seems to have a more significant number of members in France that varies between 13 and 19 members (Al-Sahafi, 2015). The effect of board size on firm profitability and value has been a matter of constant debate. Many studies state that board size is associative of more effective and efficient board committees which believed to be reducing the conflict of interest within a given company and enhancing its value (e.g., Adams and Mehran, 2011; Ahmed and Hamdan, 2015; Guo and Kumara, 2012; Najjar, 2012). According to the Saudi CG Code, the board of directors can be consisting of three to 11 members (CMA, 2011). The first sub-hypothesis to test is: 
H1-a: There is a significant and positive relationship between board size and corporate accounting and market value.

It is broadly believed that active boards should include a higher number of independent directors, where some studies suggest that a majority of independent directors may lead to better financial performance, and consequently result in reducing agency problems between shareholders and management (Cheung et al., 2007, 2011; Lei \& Song, 2012). Based on the Saudi CG code, the majority of the board of directors classified as non-executive directors, and at least one-third of them are independent (CMA, 2011). Therefore, the second subhypothesis to test is:

H1-b: There is a significant and positive relationship between board independence and corporate value and profitability.

The board meeting is usually held at specific intervals to discuss and consider significant problems and policy issues. Board meetings frequency is regarded as an essential means of establishing effective and thorough discipline processes and corporate supervision (Lei \& Song, 2012). From an agency theory perspective, numerous prior studies argue that the number of board meetings is attributed to a higher quality of managerial monitoring, and thus, better corporate value and profitability (Al-Ghamdi and Rhodes, 2015). In this sense, the Saudi CG code highlights the significance of board meetings without requiring a particular number of meetings (CMA, 2011). Therefore, the third sub-hypothesis to test is:

H1-c: There is a significant and positive relationship between the board meetings and corporate market and accounting value.

Audit Committee, as a sub-committee of the board of directors, oversees and monitors the accounting processes within a given company (Al-Sahafi et al., 2015). The size of audit committee refers to the number of members who are serving on the board (Fauziah et al., 2012). Many researchers indicate a positive and significant relationship between audit committee size and firm value (e.g., Black et al., 2012; Braga-Alves \& Shastri, 2011; Leal \& Carvalhal da Silva, 2007; Limpaphayom and Connelly, 2004; Kouwenberg, 2006; Black \& Kim, 2012). Based on the specifications of the Saudi CG code, the audit committee should not be less than three members. The members of the audit committee should not be executive directors and should include a certified accountant (CMA, 2011). Form an agency theory perspective; the audit committee is accountable for overseeing companies' financial reports, further to internal and external audit reports. The effectiveness of the audit committee can, 
therefore, reduce the likelihood of the incidence of fraud, control agency conflicts, and improve firm value (Bouaziz, 2012). The second central hypothesis to test in our study is:

H2: There is a significant and positive relationship between the audit committee size and corporate value.

Notably, there is an emphasis on the significance of the frequency of audit committee meetings in monitoring management behaviour effectively, which ultimately seemed to be leading to reducing agency costs (Limpaphayom and Connelly, 2004). There is a considerable amount of literature states that audit meetings can be attributable to better financial performance (e.g., Bebchuk and Hamdani, 2009; Black et al., 2014; Claessens and Yurtoglu, 2013). The Saudi CG code does not set a number of audit meetings, but it requires the disclosure of the number of annual audit meetings in annual reports (CMA, 2011). Therefore, the third hypothesis to test is:

H3: There is a significant and positive relationship between audit committee meetings and firm value.

In the next section, we discuss the considerations of sampling criteria and methodological choices to achieve the objectives of our study.

\section{Research design}

\section{$\underline{\text { Data and sample considerations }}$}

The population of this research is based on all financial and non-financial firms listed on Tadawul stock exchange, with complete data for the years from 2012 to 2016. Given that firm size has been believed to be related to CG compliance in the past, the sample of our paper is stratified into larger and smaller (listed) companies across both financial and nonfinancial sectors, using the same method as Ntim (2009; 2013; 2016) and Gerged et al. (2018). The stratified sampling technique is attributable to achieving a balance between large and small firms operating in different sectors, which might assist in attaining an adequate cross-sectional variation in the examined variables (Ntim, 2009). Ntim (2016), for example, investigated the relationship between CG, CSR and FV using a stratified sample consisted of the largest five and the smallest five companies in each industry. In addition, drawing on a well-established sampling technique (Stratified Samples) might help in facilitating reasonable comparisons between our results and prior evidence (e.g., Al-Bassam et al., 2018; Elmagrhi et al., 2016; Elmagrhi et al., 2017; Ntim, 2016). 
Our sample, therefore, consisted of 300 observations $^{1}$ (60 company, representing $34.29 \%$ of the overall population of listed companies in Saudi Arabia, which is statistically acceptable) Over five years. Different datasets were combined to investigate the questions of our research. The predictor variable, outcome variable and controls have been mainly collected from companies' annual reports that published on the official website of the Tadawul stock market, supplemented with Trade Mubasher Database, and Perfect Information Database.

\section{Measures}

Table 1 below explains how our variables have been operationally defined. In examining our research hypotheses, we divide our work into four stages. First, we measure firm market value using Tobin's Q ration, and we employ ROA and ROE as proxies for firm profitability or firm accounting value (Haslam et al. 2010; Baghat and Bolton, 2008; Mazzotta et al., 2017). Second, we use the main proxies for corporate governance (CG) internal mechanisms, which are the board size, meetings, and independence, and audit committee size and meetings. Third, in an attempt to tackle potential endogeneities connecting to omitted variables, a set of firm-specific characteristics has been employed to control for the relationship between CG and FV in our study (Gujarati, 2003; Wooldridge, 2010). The selected control variables are the firm size (SIZE), leverage (LEV), sector type (SEC), and audit type (big4). These control variables have been selected to be in line with previous CG literature (See Crifo \& Forget, 2015; Fifka, 2013; Ntim, 2016). Fourth, the present paper investigates the relationship between CG compliance and firm market and accounting value using a fixed-effects estimation to test the primary hypotheses, and a generalised method of moment (GMM) model to address any concerns regarding omitted variables and the possible existence of endogeneity problems.

\section{INSERT TABLE 1 ABOUT HERE}

\section{$\underline{\text { Analysis }}$}

Fixed-effects estimators have been used as principal regression analysis in our study. Fixedeffects estimation addresses those statistical issues that might not be tackled by estimating an

\footnotetext{
${ }^{1}$. The data has been manually collected for corporate governance, firm value, and firm-specific characteristics from annual reports, which consumed a long time and needed a great effort. Creating a non-existent dataset about the CG-FV nexus in Saudi Arabia is regarded as one of our empirical contributions.
} 
ordinary least squares (OLS) model (Gerged et al., 2019). For example, it controls for unobservable firm-specific heterogenous variables over time that is probably constant, yet can affect the outcome-predictor nexus (Glass et al., 2015; Ntim and Soobaroyen, 2013) which an OLS model might fail to identify (Gujarati, 2003; Wooldridge, 2010). Consequently, the regression analysis in our study starts with conducting fixed-effects models based on the three proxies of the dependent variable (FV), which can be specified as below:

$$
\begin{gathered}
F V_{i t}=\alpha_{0}+\beta_{1} \text { BSIZE }_{i t}+\beta_{1} \text { BINDP }_{i t}+\beta_{1} B M E_{i t}+\beta_{1} \text { AUCSIZE }_{i t}+\beta_{1} \text { AUCME }_{i t} \\
+\sum_{i=1}^{n} \beta_{i} \operatorname{CONTROLS~}_{i t}+y_{i}+\varepsilon_{i t}
\end{gathered}
$$

Where FV is firm value as measured by Tobin' Q ( TBQ), return on assets (ROA) and return on equity (ROE), BSIZE is board size, BINDP is board independent, BME is a board meeting, AUCSIZE is audit committee size, AUCME is audit committee meetings. CONTROLS are firm size proxied by total assets (TA), leverage proxied by debt to assets (DOA), industry type (INDUS), and finally, audit type (BIG4).

In an attempt to ensure the appropriateness of selecting a fixed-effects estimator over a random-effects one, a Hausman test was implemented. Hausman test confirms the suitability of a fixed-effects model. Specifically, it suggests that the un-observed firm heterogeneities were insignificantly related to those of the other firms in the sample of the present study.

\section{Results and discussion}

\section{Results}

Table 2 presents the descriptive statistics for our variables for all 300 firm-year observations. Our results indicate substantial variability in the distributional properties of the variables. For example, firm market value (FV) proxied by TBQ varies from a minimum of -0.73 to a maximum of 8.67 , with an average of 2.342. Likewise, a variation has been noted in our results regarding firm accounting value as measured by ROA with a standard deviation of 0.058 and 0.02 mean value. Similarly, the mean value of board size (BSIZE) is 8.525 with 1.557 standard deviations.

INSERT TABLE 2 ABOUT HERE 
Table 3 below shows the correlation analysis of the variables. It reports the coefficients of both Pearson (parametric) and Spearman (non-parametric) correlations. The parallel nature of both Pearson and Spearman coefficients indicates that any residual non-normally distributed variables in our study might be mild, and are also similar to those reported by prior work (e.g., Cho et al., 2013; Cormier et al., 2011; Lu \& Abeysekera, 2014). Importantly, the magnitude and direction of both Pearson and Spearman coefficients are primarily comparable, thus suggesting that any residual non-normalities are less likely to result in severe statistical problems.

\section{INSERT TABLE 3 ABOUT HERE}

The central hypothesis in the current paper predicts that a company complied with good CG practices is highly likely to have higher firm market value and better financial performance in Saudi Arabia. The results indicate that the effects of compliance with CG mechanisms on FV and profitability in Saudi Arabia are heterogeneous in that they might have either enhanced or reduced FV. In the correlations matrix (refer to Table 3), FV proxied by TBQ is indeed positively and significantly related to board size (BSIZE) and audit committee meetings (AUCM). Likewise, once the Fixed-Effects models were estimated with the other firmspecific characteristics of interest controlled, this significant and positive association has been confirmed (see Table 4 column 1). However, the remaining CG mechanisms (i.e., BINDEP, BME, and AUCSIZ) cannot predict FV as measured by TBQ in our sampled companies. This means that H1-a and H3 have been statistically accepted, whereas H1-b, H1-c, and H2 have been rejected using TBQ as a proxy for FV (Refer to Table 4 columns 2 and 3).

On the other hand, using ROA as a proxy for firm profitability or financial performance, our results suggest that only audit committee size has a significant impact on firm profitability, while there is no other mechanism has an effect on firm profitability using ROE as a proxy (See Table 4 columns 2 and 3).

INSERT TABLE 4 ABOUT HERE 
Notably, nevertheless not the primary focus of our study, the control variables (firm-specific characteristics) have different effects on firm value. For example, audit quality, as measured by big4, is positively and significantly associated with FV, whereas sector type (financial or non-financial sectors) has a negative impact on FV. This means that CG mechanisms are more attributed to FV in non-financial firms as compared to their financial counterparts. This result is in line with prior evidence argues that many of the financial crises have been attributable to a lack of rigorous CG compliance among banks and other financial institutions (Ntim, 2009). Haque et al. (2007), for instance, raises severe concerns on CG compliance in the banking sector and criticises CG quality that prevails in the financial industry. In other words, the efficiency and effectiveness of CG internal mechanisms in the Saudi financial institutions are questionable, especially after the implementation of the British voluntary CG system ‘comply-or-explain’ after 2011.

\section{Further Robustness Checks}

Arellano and Bond (1991) argue that panel data regressions may not be reliably conducted by using fixed-effects models only since the regressor is not firmly exogenous.

Previous empirical research, which attempted to examine the causes and consequences of the process of corporate financial decisions, has regularly encountered severe concerns with endogeneity (Redor, 2018; Wintoki et al., 2012). For example, unobserved endogeneity and heterogeneity emerged from a non-zero correlation between a regressor and the company fixed-effects is a commonly known concern in CG research (Roberts and Whited, 2011). Similarly, the occurrence of residual autocorrelation can violate one of the primary assumptions of GMM estimators (Arellano and Bond, 1991). In empirical CG research, serial correlation can result from financial variable persistence, the existence of measurement errors or employing a functional form incorrectly such as linear versus non-linear estimations (Welch, 2011; Kusi et al., 2018). In an effort to address the concerns of the potential existence of unobserved endogeneities and heterogeneities, we follow previous CG-to-FV research (e.g., Beiner et al., 2006; Gerged, 2018; Gerged et al., 2019; Moumen et al., 2015; Ntim et al., 2013; Reguera-Alvarado et al., 2016; Roberts and Whited, 2011; Welch, 2011; Wintoki et al., 2012) by estimating a GMM model as a further robustness check.

The results of applying a GMM model are supportive of the earlier inferences obtained from estimating fixed-effects models. In other words, estimating GMM models still yield a heterogeneous association between CG mechanisms and FV proxies. For example, BZISE 
and AUCME were attributed to firm market value (TBQ), whereas both cannot predict firm accounting value proxied by ROA and ROE (refer to Table 4, panels 4 to 6). Similarly, BINDEP is still negatively associated with all firm value proxies. This means that our results are unlikely to be largely affected by the occurrence of endogeneity problems.

\section{Discussion}

Our results are consistent with a significant amount of previous CG studies in developing countries. In particular, our findings are in line with Al-Sahaf (2015) that reported a positive and significant relationship between board size and firm market value proxied by TBQ. Similarly, our results are tied to Davidson and Rowe (2004), and Rashid et al. (2010) that concluded that there is no significant and/or negative relationship between independent directors and firm performance. Our evidence is also in line with Wintoki et al. (2012) that indicate a negative association between BIDEP and FV. Theoretically, Hermalin and Weisbach's (1998) argue that board characteristics are partly considered as a bargaining process function between the CEO of a company and the board of directors, and that since the bargaining position of a CEO could be a function of the board's ability, proxied by backwards-looking firm financial performance measures, board structure relies on firm value. In line with this theoretical argument, we conclude that BIDEP is negatively attributed to FV. We argue that independent directors' presence in Saudi listed companies is unlikely to enhance the role of governance standards as a watching tool for risk management in Saudi Arabia, which is in contradiction of the main claim of agency framework. This implies that the number of insiders seemed to have presumably reduced outside directors' ability to enhance firm financial performance in the context of the study.

Al-Matari et al. (2012) are indicative of a significant and positive relationship between audit committee number of meetings (AUCME) and firm financial performance that is empirically consistent with the outcomes of our investigation. In contrast, the noted insignificant association between audit committee size (AUCSIZE) and FV proxies, raising doubts that AUCSIZE does not enhance firms' financial performance in Saudi Arabia. A body of empirical CG research gives credibility to our results, for example, Akinteye et al. (2015), Tanyi and Smith (2014).

In addition, our results are very consistent with the outcomes of previous studies that have examined CG practices among companies working in countries that have adopted the UK 
voluntary compliance style (e.g., Aguilera and Cuervo-Cazurra, 2009; Filatotchev and Boyd, 2009; Ntim, 2009). Specifically, those have adopted the 'comply-or-explain' compliance regime. In this regard, Aguilera and Cuervo-Cazurra (2009, p.376) state that:

“Despite the criticisms that the codes' voluntary nature limits their ability to improve governance practices, codes of good governance appear to have generally improved the governance of countries that have adopted them, although there is the need for additional reforms ”.

A vital feature of the UK CG style is that it supports codes of good CG practices to be appended to broad listings rules for listed companies to comply with (Ntim, 2009). They are nevertheless regarded to be a voluntary type of practices because CG provisions in Saudi Arabia are not mainly enforceable by law, and listed firms might not necessarily be held accountable for not conforming with a specific CG provision if they have offered a reasonable explanation. Our results suggest that applying CG codes voluntarily after 2011 has yet to yield financial consequences for companies in Saudi Arabia. This implies that developing other mandatory enforcement mechanisms for CG provisions, such as appending good CG practices to listing rules for companies to comply with, might lead to better financial results for those well-governed companies in Saudi Arabia. This implication is in line with the results of Low and Cowton (2004) that concluded that companies' compliance with CG codes might be subject to legal enforcement.

Our findings broadly suggest that, irrespective of FV measure used (i.e., whether a market measure (TBQ-ratio) or an accounting measure (ROA and ROE)), the effects of CG mechanisms on FV are heterogeneous in that they might have either encouraged or discouraged FV in Saudi Arabia after adopting the 2011 CG compliance regime 'comply-orexplain'. This implies that, averagely, better-governed Saudi listed companies tend to be categorised with higher market value than their poorly governed counterparts are. However, CG mechanisms cannot predict firm profitability (i.e., proxied by ROA and ROE) in Saudi Arabia.

\section{Conclusion}

Our results are suggestive of heterogeneous effects of CG mechanisms on firm value and profitability. In particular, board size and audit committee meetings are both positively and significantly associated with firm value as measured by TBQ, whereas board independence, board meetings, and audit committee size cannot predict either firm accounting value or market value. This means that, averagely, companies with better CG compliance appeared to 
have generally achieved a better market value, but not necessarily better profitability. This implies that adopting the 2011 CG compliance regime in Saudi Arabia seemed to have a limited impact, so far, on FV and profitability during the period of study (i.e., 2012 to 2016).

Given the voluntary nature of CG compliance regime of 'comply-or-explain' in Saudi Arabia, listed firms are not necessarily held accountable for not complying with a specific CG provision if they provided a reasonable explanation. The policy implication of our results is therefore centred on the need for developing a legal mechanism to make the compliance with CG codes enforceable by law in Saudi Arabia such as appending good CG practices to full listings rules for publicly listed companies to comply with.

Notwithstanding the exertions to confirm the robustness of our results, several limitations should be acknowledged. For instance, the sample of our investigation consisted only of 60 publicly listed Saudi firms. Future studies can try to include more firms and sectors. In addition, future work should focus on investigating the combined effect of internal and external CG mechanisms on FV in Saudi Arabia to offer a more comprehensive understanding of the CG-FV nexus. Despite these limitations and others, it is hoped that the current paper will inspire further investigations in this research area. 


\section{References}

Abdallah, A.A.N. and Ismail, A.K. (2017). 'Corporate governance practices, ownership structure, and corporate performance in the GCC countries'. Journal of International Financial Markets, Institutions and Money, Vol. 46, pp. 98-115.

Adams, R., \& Mehran, H. (2011). 'Corporate Performance, Board Structure, and Their Determinants in the Banking Industry'.Federal Reserve Bank of New York.Staff Reports.no 330. 1-49.]

Aguilera, R. V. and Cuervo-Cazurra, A. (2009), 'Codes of good governance', Corporate Governance: An International Review, Vol. 17 No. 3, pp.376-387.

Ahmed, E. and Hamdan, A. (2015). 'The impact of corporate governance on firm performance: evidence from Bahrain Bourse'. International Management Review, Vol, 11 N. 2, pp.21-37.

Akinteye, S.A., York, D.O. and Quat-Ullah, H. (2015). 'Corporate Governance Mechanism: An Investigation of the Internal Audit Function Quality in Nigerian Listed Firms'. International Journal of Business and Social Science, Vol. 6, No. 1, pp. 18-33.

Alamri, K., Milman, D. and Lawton, P. (2018). The board of directors in listed companies under the corporate governance system in Saudi law as compared to English law and global standards (Doctoral dissertation, Lancaster University).

Al-Bassam, W.M., Ntim, C.G., Opong, K.K. and Downs, Y. (2018). 'Corporate boards and ownership structure as antecedents of corporate governance disclosure in Saudi Arabian publicly listed corporations’. Business \& Society, Vol. 57, No. 2, pp.335-377.

Al-Ghamdi, M., \& Rhodes, M. (2015). 'Family Ownership, Corporate Governance and Performance: Evidence from Saudi Arabia'. International Journal of Economics and Finance, Vol. 7 No. 2, pp, 78-89.

ALGhamdi, S. (2012). 'Investigation into Earnings Management Practices and the Role of Corporate Governance and External Audit in Emerging Markets: Empirical Evidence from Saudi Listed Companies’. (PhD thesis - Durham University).

Al-Habshan, K.S. (2015). 'Corporate governance disclosure practices and protection of shareholders in Saudi Arabia', (Doctoral dissertation, Brunel University London).

AL-kahtani, F. S. (2013). 'Current practices of Saudi corporate governance: a case for reform.school of law', (Doctoral dissertation, Brunel University).

Al-Matari, Y. A., Al-Swidi, A. K., Bt Fadzil, F. H., \& Al-Matari, E. M. (2012). 'Board of Directors, Audit Committee Characteristics and the Performance of Saudi Arabia Listed Companies'. International Review of Management and Marketing, Vol. 2 No. 4, pp 241251.

Al-Sahafi, A., Rodrigs, M., \& Barnes, L. (2015). 'Does Corporate Governance Affect Financial Performance in Banking Sector'? Evidence from Saudi Arabia. International Journal of Economics, Commerce, and Management, Vol. 3 No. 3, pp 1-26.

Ammann, M., Oesch, D., \& Schmid, M. M. (2011). 'Corporate governance and firm value: International evidence’. Journal of Empirical Finance, Vol. 18 No. 1, pp 36-55. 
Ararat, M., Black, B.S. and Yurtoglu, B.B. (2017). 'The effect of corporate governance on firm value and profitability: Time-series evidence from Turkey'. Emerging Markets Review, Vol. 30 No. 2, pp.113-132.

Arellano, M., \& Bond, S. (1991). 'Some tests of specification for panel data: Monte Carlo evidence and an application to employment equations'. The Review of Economic Studies, Vol. 58 No. 2, pp. 277-297.

Baghat, S. and Bolton, B. (2008) 'Corporate governance and firm performance', Journal of Corporate Finance, Vol. 14, No. 3, pp.257-273.

Balasubramanian, N., Black, B.S. and Khanna, V. (2010). 'The relation between firm-level corporate governance and market value: A case study of India'. Emerging Markets Review, Vol. 11 No. 4, pp.319-340.

Bebchuk, L. A., \& Hamdani, A. (2008). The elusive quest for global governance standards'. U. Pa. L. Rev., Vol. 157 No. 5, pp 1263-1316.

Beiner, S., Drobetz, W., Schmid, M. M., \& Zimmermann, H. (2006). 'An integrated framework of corporate governance and firm valuation'. European Financial Management, Vol. 12, No. 2, pp. 249-283.

Belkhir, M. (2009). 'Board of directors' size and performance in the banking industry'. International Journal of Managerial Finance, Vol. 5 No. 2, 201-221.

Black, B. (2001). 'The corporate governance behaviour and market value of Russian firms'. Emerging Markets Review, Vol. 2 No. 2, pp.89-108.

Black, B., De Carvalho, A.G., Khanna, V., Kim, W. and Yurtoglu, B. (2014). 'Methods for multi-country studies of corporate governance: Evidence from the BRIKT countries'. Journal of Econometrics, Vol. 183 No. 2, pp.230-240.

Black, B.S., De Carvalho, A.G. and Gorga, É. (2012). 'What matters and for which firms for corporate governance in emerging markets? Evidence from Brazil (and other BRIK countries)'. Journal of Corporate Finance, Vol. 18 No. 4, pp.934-952.

Blundell, R. and Bond, S. (1998). 'Initial conditions and moment restrictions in dynamic panel data models’. Journal of Econometrics, Vol. 87, No. 1, pp.115-143.

Bouaziz, Z. (2012). 'The Impact of the Presence of Audit Committees on the Financial Performance of Tunisian Companies.Faculty of Economics and Management of Sfax Accounting Department, Tunisia'.Issn: 2230-9519 (online) http://www.ijmbs.com/24/zied.pdf.

Boubaker, S., \& Nguyen, D. K. (2014). 'Corporate governance in emerging markets: Theories, practices and cases’. Berlin, Heidelberg: Springer.

Braga-Alves, M.V. and Shastri, K. (2011). 'Corporate governance, valuation, and performance: evidence from a voluntary market reform in Brazil'. Financial Management, Vol. 40 No. 1, pp.139-157.

Brown, L. D., \& Caylor, M. L. (2006). 'Corporate governance and firm valuation'. Journal of Accounting and Public Policy, Vol. 25 No. 4, pp 409-434.

Buallay, A., Hamdan, A. and Zureigat, Q. (2017). 'Corporate governance and firm performance: evidence from Saudi Arabia'. Australasian Accounting, Business and 
Finance Journal, Vol. 11, No. 1, pp.78-98.

Cheung, Y.L., Thomas Connelly, J., Limpaphayom, P. and Zhou, L. (2007). 'Do investors really value corporate governance? Evidence from the Hong Kong market'. Journal of International Financial Management \& Accounting, Vol. 18 No. 2, pp.86-122.

Chhaochharia, V., \& Grinstein, Y. (2007). 'Corporate governance and firm value: The impact of the 2002 governance rules'. The Journal of Finance, Vol. 62 No. 4, 1789-1825.

Cho, S.Y., Lee, C. and Pfeiffer Jr, R.J. (2013). 'Corporate social responsibility performance and information asymmetry’. Journal of Accounting and Public Policy, Vol. 32 No. 1, pp.71-83.

Choo, C. (2008). 'Organizational disasters: why they happen and how they may be prevented’. Management Decision, Vol. 46 No. 1, pp.32-45.

Claessens, S. and Yurtoglu, B.B. (2013). 'Corporate governance in emerging markets: A survey’. Emerging Markets Review, Vol. 15 No. 4, pp.1-33.

CMA. (2007). 'The Capital Market Authority, Annual Report 2007'. available at: https://cma.org.sa/en/AboutCMA/AnnualReport/Documents/cma_2007_report.pdf.

CMA. (2009). 'The Capital Market Authority, Annual Report 2009'. available at:https://cma.org.sa/en/AboutCMA/AnnualReport/Documents/cma_2009_report.pdf.

CMA. (2011). 'The Capital Market Authority, Annual Report 2011'. available at: https://cma.org.sa/en/AboutCMA/AnnualReport/Documents/cma_2011_report.pdf.

Cormier, D., Ledoux, M. J., \& Magnan, M. (2011). 'The informational contribution of social and environmental disclosures for investors'. Management Decision, Vol. 49 No. 8, pp. 1276-1304.

Crifo, P. and Forget, V.D. (2015). 'The economics of corporate social responsibility: A firmlevel perspective survey’. Journal of Economic Surveys, Vol. 29 No. 1, pp.112-130.

Dahya, J., Dimitrov, O. and McConnell, J.J. (2008). 'Dominant shareholders, corporate boards, and corporate value: A cross-country analysis'. Journal of Financial Economics, Vol. 87 No. 1, pp.73-100.

Deegan, C. and Rankin, M. (1997). 'The materiality of environmental information to users of annual reports'. Accounting, Auditing \& Accountability Journal, Vol. 10, No. 4, pp.562583.

Durnev, A. and Kim, E.H.A.N. (2005). 'To steal or not to steal: Firm attributes, legal environment, and valuation'. The Journal of Finance, Vol. 60 No. 3, pp.1461-1493.

Elmagrhi, M. H., Ntim, C. G., \& Wang, Y. (2016). 'Antecedents of voluntary corporate governance disclosure: A post-2007/08 financial crisis evidence from the influential UK combined code'. Corporate Governance: The International Journal of Business in Society, Vol. 16 No. 3, 507-538.

Elmagrhi, M.H., Ntim, C.G., Crossley, R.M., Malagila, J.K., Fosu, S. and Vu, T.V. (2017). 'Corporate governance and dividend payout policy in the UK listed SMEs’. International Journal of Accounting \& Information Management, Vol. 25 No. 4, pp.459-483.

Elsayed, K. (2011). 'Board size and corporate performance: The missing role of board 
leadership structure’. Journal of Management \& Governance, Vol. 15 No. 3, 415-446.

Epstein, M.J. and Freedman, M. (1994). 'Social disclosure and the individual investor’. Accounting, Auditing \& Accountability Journal, Vol. 7, No. 4, pp.94-109.

Fallatah, Y., \& Dickins, D. (2012). 'Corporate governance and firm performance and value in Saudi Arabia’. African Journal of Business Management, Vol. 6 No. 36, pp, 1002510034.

Fama, E. F., \& Jensen, M. C. (1983). 'Separation of ownership and control'. Journal of Law and Economics, Vol. 26, No. 2, pp. 301-325.

Fifka, M.S. (2013). 'Corporate responsibility reporting and its determinants in comparative perspective-a review of the empirical literature and a meta-analysis'. Business Strategy and the Environment, Vol. 22 No. 1, pp.1-35.

Filatotchev, I. and Boyd, B. K. (2009), 'Taking stock of corporate governance research while looking to the future', Corporate Governance: An International Review, Vol. 17 No. 3, pp.257-265.

Gerged A., Al-Haddad L., and Al-Hajri, M. (2019). 'Is earnings management associated with corporate environmental disclosure? Evidence from Kuwaiti listed firms’. Accounting Research Journal. DOI: 10.1108/ARJ-05-2018-0082 (In press).

Gerged, A.M. (2018). 'Corporate Environmental Disclosure in the Arab Middle Eastern and North African Region: An Institutional Perspective'. (Doctoral dissertation, University of Huddersfield).

Gerged, A.M., Cowton, C.J. and Beddewela, E.S. (2018). 'Towards Sustainable Development in the Arab Middle East and North Africa Region: A Longitudinal Analysis of Environmental Disclosure in Corporate Annual Reports'. Business Strategy and the Environment, Vol. 27 No. 4, pp.572-587.

Ghabayen, M. (2012). 'Board characteristics and firm performance: Case of Saudi Arabia'. International Journal of Accounting and Financial Reporting, Vol. 2 No. 2, pp.168-200.

Glass, C., Cook, A., \& Ingersoll, A. R. (2016), “Do women leaders promote sustainability? Analyzing the effect of corporate governance composition on environmental performance”. Business Strategy and the Environment, Vol. 25 No. 7, pp. 495-511.

Grassa, R. and Matoussi, H. (2014). 'Is corporate governance different for Islamic banks? A comparative analysis between the Gulf Cooperation Council and Southeast Asian countries‘. International Journal of Business Governance and Ethics, 9(1), pp.27-51.

Gujarati, D. and Porter, D. (2003). 'Multicollinearity: What happens if the regressors are correlated’. Basic Econometrics, McGraw-Hill New York.

Guo, Z., \& Kumara, U. (2012). 'Corporate governance and firm performance of listed firms in Sri Lanka. Journal of Social Behavior Science’, Vol. 40 No. 4, pp. 664-667.

Habbash, M. and Alghamdi, S. (2017). 'Audit quality and earnings management in less developed economies: the case of Saudi Arabia'. Journal of Management \& Governance, Vol. 21 No. 2, pp. 351-373.

Hamdan, A. M., Sarea, A. M., \& Reyad, S. M. (2013). 'The impact of audit committee characteristics on the performance: Evidence from Jordan'. International Management 
Review, Vol. 9 No. 1, pp. 32-42.

Haniffa, R., \& Hudaib, M. (2006). 'Corporate governance structure and performance of Malaysian listed companies'. Journal of Business Finance \& Accounting, Vol. 33, No. (7 - 8), pp. 1034-1062.

Haque, D.A., Jalil, M.B. and Naz, F. (2007). 'State of Corporate Governance in Bangladesh Analysis of Public Limited Companies-Financial, Non-Financial Institutions and StateOwned Enterprises'. Working Paper Series, No. 2, pp. 1-23.

Haslam, S.A., Ryan, M.K., Kulich, C., Trojanowski, G. and Atkins, C. (2010) 'Investing with prejudice: the relationship between women's presence on company boards and objective and subjective measures of company performance', British Journal of Management, Vol. 21, No. 2, pp.484-497.

Herdjiono, I., \& Sari, I. M. (2016). 'The Effect of Corporate Governance on the Performance of a Company. Some Empirical Findings from Indonesia.Journal of Management and Business Administration’. Central Europe.Vol. 25, No. 1, pp. 33-52.

Hermalin, B.E. and Weisbach, M.S. (1988). 'The determinants of board composition'. The Journal of Economics, pp.589-606.

Issarawornrawanich, P. (2015). 'The Association between Board of Directors' Characteristics and Firm Performance: Empirical Evidence from Emerging Market of Thailand'. Journal of Applied Business and Economics, Vol. 17 No. 1, pp. 54-65.

Jensen, M. C., \& Meckling, W. H. (1976). 'Theory of the firm: Managerial behaviour, agency costs and ownership structure'. Journal of Financial Economics, Vol. 3, No. 4, 305-360.

Jensen, M. C., \& Meckling, W. H. (1976). 'Theory of the firm: managerial behaviour, agency costs. Journal of Financial Economics, Vol. 3 No. 4, pp. 305-360.

Jo, H., \& Harjoto, M. A. (2011). 'Corporate governance and firm value: The impact of corporate social responsibility’. Journal of Business Ethics, Vol. 103 No. 3, pp. 351-383.

Kaymak, T. and Bektas, E. (2017). 'Corporate social responsibility and governance: information disclosure in multinational corporations'. Corporate Social Responsibility and Environmental Management, Vol. 24 No. 6, pp. 555-569.

Kennedy, P. (2008). 'A guide to econometrics’. (6th ed). Malden, Mass; Oxford; Blackwell.

Khan, A., \& Awan, S. H. (2012). 'Effect of board composition on firm performance: Access of Pakistani listed companies'. Interdisciplinary Journal of Contemporary Research in Business.’ Vol 3 No. 10. pp,1-11.

Klapper, L.F. and Love, I. (2004). 'Corporate governance, investor protection, and performance in emerging markets'. Journal of Corporate Finance, Vol. 10 N0. 5, pp.703-728.

Klein, A. (1998). 'Firm performance and board committee structure'. Journal of Law and Economics, Vol. 41, No. 1, pp. 275-304.

Kouwenberg, R. (2006). 'Does voluntary corporate governance code adoption increase firm value in emerging markets? Evidence from Thailand'. http://ssrn.com/ abstract $=958580$

Kusi, B. A., Dzeha, G. C., Ofori-Sasu, D., \& Ansah-Addo, L. (2018). Corporate governance 
structures and bank risk-taking behaviour: evidence from Africa using income bracket approach. International Journal of Business Governance and Ethics, Vol. 13, No. 2, 138-169.

Kuznecovs, M., Pal, S. (2012). 'Does Corporate Governance Reform necessarily Boost Firm Performance? Recent Evidence from Russia’. IZA Discussion Paper No. 6519 (Available at SSRN: http://ssrn.com/abstract=2051362)

Leal, R.P. and Carvalhal-da-Silva, A.L. (2007). 'Corporate governance and value in Brazil (and in Chile)'. Investor protection and corporate governance: Firm-level evidence across Latin America, pp. 213-287.

Lei, A.C. and Song, F.M. (2012). 'Board structure, corporate governance and firm value: evidence from Hong Kong’. Applied Financial Economics, Vol. 22 No. 15, pp.12891303.

Limpaphayom, P., Connelly, J.T. (2004). 'Review of Corporate Governance in Asia: Corporate Governance in Thailand.' Thai Institute of Directors Association, Bangkok.

Low, C., \& Cowton, C. (2004). Beyond stakeholder engagement: the challenges of stakeholder participation in corporate governance. International journal of business governance and ethics, Vol. 1, No. 1, pp. 45-55.

Lu, Y. and Abeysekera, I. (2014). 'Stakeholders' power, corporate characteristics, and social and environmental disclosure: Evidence from China'. Journal of Cleaner Production, Vol. 64, pp.426-436.

Mazzotta, R., Bronzetti, G. and Baldini, M.A. (2017). Does board diversity affect firm performance? Evidence from the Italian financial sector. International Journal of Business Governance and Ethics, Vol. 12, No. 1, pp.65-89.

Mezghani, I., \& Haddad, H. B. (2017). 'Energy consumption and economic growth: An empirical study of electricity consumption in Saudi Arabia'. Renewable and Sustainable Energy Reviews, Vol. 75, 145-156.

Moumen, N., Othman, H. B., \& Hussainey, K. (2015). 'The value relevance of risk disclosure in annual reports: Evidence from MENA emerging markets'. Research in International Business and Finance, Vol. 34, pp.177-204.

Najjar, N. (2012). 'The Impact of Corporate Governance on the Insurance Firm's Performance in Bahrain'. International Journal of Learning \& Development, Vol. 2, No. 2, pp. 1-17.

Narwal, K. P., \& Jindal, S. (2015). 'The Impact of Corporate Governance on the Profitability: An Empirical Study of Indian Textile Industry'. International Journal of Research in Management, Science \& Technology, Vol. 3, No. 2, pp. 81-85.

Ntim, C. G. (2009), 'Internal corporate governance structures and firm financial performance: Evidence from South African listed firms'. PhD Thesis, (University of Glasgow-UK), pp. 1-426.

Ntim, C. G. (2016). 'Corporate governance, corporate health accounting, and firm value: The case of HIV/AIDS disclosures in sub-Saharan Africa'. The International Journal of Accounting, Vol. 51 No. 2, 155-216.

Ntim, C. G., \& Osei, K. A. (2011). 'The impact of corporate board meetings on corporate 
performance in South Africa'. African Review of Economics and Finance, Vol. 2 No. 2, pp. 83-103.

Ntim, C. G., \& Soobaroyen, T. (2013), 'Black economic empowerment disclosures by South African listed corporations: The influence of ownership and board characteristics'. Journal of Business Ethics, Vol. 116, No. 1, pp. 121-138.

Ntim, C. G., Lindop, S., \& Thomas, D. A. (2013). 'Corporate governance and risk reporting in South Africa: A study of corporate risk disclosures in the pre-and post-2007/2008 global financial crisis periods'. International Review of Financial Analysis, Vol. 30, pp. 363-383.

Ntim, C.G. (2013). 'Corporate ownership and market valuation in South Africa: Uncovering the effects of shareholdings by different groups of corporate insiders and outsiders'. International Journal of Business Governance and Ethics, Vol. 8, No. 3, pp.242 - 264.

Ntim, C.G., Opong, K.K., Danbolt, J. and Thomas, D.A. (2012). 'Voluntary corporate governance disclosures by post-apartheid South African corporations'. Journal of Applied Accounting Research, Vol. 13 No. 2, pp.122-144.

Olaleke, F. I., Onakoya, A. B., \& Ofoegb, D. I. (2014). 'Corporate Governance as Correlate for Firm Performance: A Pooled OLS Investigation of Selected Nigerian Banks'.The IUP Journal of Corporate Governance, Vol. XIII No. 1, pp. 7-18.

Piesse, J., Strange, R., \& Toonsi, F. (2012). 'Is there a distinctive MENA model of corporate governance?’ Journal of Management \& Governance, Vol. 16 No. 4, pp. 645-681.

Pillai, R. R., \& Al-Malkawi, H. N. (2016). 'Corporate governance in the GCC countries: Empirical assessment using conventional and non-conventional indices'. The Journal of Developing Areas, Vol. 50 No. 6, pp. 69-88.

Quttainah, M. A., Cocco, J., \& Al-Zufairi, A. (2017). The determinants of the effectiveness of corporate governance at Islamic banks. International Journal of Business Governance and Ethics, 12(2), 174-196.

Redor, E. (2018). Gender diversity on corporate boards: does critical mass matter to investors?. International Journal of Business Governance and Ethics, 13(2), 199-216.

Reguera-Alvarado, N., Blanco-Oliver, A. and Martín-Ruiz, D. (2016). 'Testing the predictive power of PLS through cross-validation in banking'. Journal of Business Research, Vol. 69, No, 10, pp.4685-4693.

Rezaee, Z. (2009). 'Corporate governance and ethics'. John Wiley \& Sons ISBN: 9780471738008.

Roberta, R., Sanjai, B., \& Brian B. (2008). 'The Promise and Peril of Corporate Governance Indices’, Columbia Law Review, Vol. 108 No. 8, pp. 1803-1882.

Roberts, M.R., Whited, T.M. (2011). 'Endogeneity in empirical corporate finance'. In: Constantinides, M., Stulz, R. (Eds.), Handbook of the Economics of Finance. Vol. 2. Elsevier.

Ross, S.A., 1973. The economic theory of agency: The principal's problem. The American Economic Review, Vol. 63, No. 2, pp.134-139. 
Salloum, C., Bouri, E. and Khalife, D. (2013). 'Board of directors and bank performance: beyond agency theory'. International Journal of Business Governance and Ethics, Vol. 8, No. 3, pp.265-288.

Sarkar, J. and Sarkar, S. (2012). 'Corporate governance in India'. SAGE Publishing India.

Sarpal, S., \& Singh, F. (2013). 'Board size and corporate performance: An empirical investigation'. International Journal of Business Ethics in Developing Economies, Vol. 2 No. 1, pp. 1-8.

Saunders, M., Lewis, P., \& Thornhill, A. (2016). 'Research methods for business students (Seventh ed.)'. Harlow: Pearson Education.

Sulong, Z. and Ahmed, P.K. (2011). 'Ownership structure, board governance, dividends and firm value: an empirical examination of Malaysian listed firms', Int. J. Business Governance and Ethics, Vol. 6, No. 2, pp.135-161.

Sunday, K. (2008). 'Corporate governance and firm performance: the case of Nigerian listed firms'. European Journal of Economics, Finance and Administrative Sciences ISSN 1450-2275 Issue, 17-28.

Sweet, S. A., \& Grace-Martin, K. (2008). 'Data analysis with SPSS: A first course in applied statistics (3rd ed.)’. Boston, Mass; London; Pearson Allyn and Bacon.

Tadawul. (2007). Saudi Stock Exchange (Tadawul), Annual Report. Available at:https://www.tadawul.com.sa/wps/wcm/connect/51c977cb-e0f8-4361-9988-

80aea4d6df15/Annual_Report_2007_English.pdf?MOD=AJPERES\&CONVERT_TO=u rl\&CACHEID=51c977cb-e0f8-4361-9988-80aea4d6df15

Tanyi, P.N. and Smith, D.B. (2014). 'Busyness, expertise, and financial reporting quality of audit committee chairs and financial experts'. Auditing: A Journal of Practice \& Theory, Vol. 34 No. 2, pp.59-89.

Wagner, M. (20050. 'How to reconcile environmental and economic performance to improve corporate sustainability: corporate environmental strategies in the European paper industry'. Journal of Environmental Management, Vol. 76 No. 2, pp.105-118.

Walt, N., \& Ingley, C. (2003). 'Board dynamics and the influence of professional background, gender and ethnic diversity of directors'. Corporate Governance: An International Review, Vol. 11, No. 3, pp. 218-234.

Welch, I. (2011). 'Two common problems in capital structure research: The financial-debt-toasset ratio and issuing activity versus leverage changes'. International Review of Finance, Vol. 11, No. 1, pp.1-17.

Wintoki, M.B., Linck, J.S. and Netter, J.M. (2012). 'Endogeneity and the dynamics of internal corporate governance’. Journal of Financial Economics, Vol. 105, No. 3, pp.581-606.

Wooldridge, J.M., 2010. Econometric analysis of cross section and panel data. MIT press.

Yaser, F., \& Denise, D. (2012). 'Corporate governance and firm performance and value'. African Journal of Business Management, Vol. 6 No. 36, pp. 10025-10034, Available online

http://www.academicjournals.org/article/article1380795217_Fallatah\%20and\%20Dickin s.pdf. 
Yasser, Q. R., Entebang, H., \& Mansor, S. A. (2011). 'Corporate governance and firm performance in Pakistan'. Journal of Economics and International Finance, Vol. 3 No. 8, pp. 482-491.

Yusoff, W. F., \& Alhaji, I. A. (2012). 'Corporate Governance and Firm Performance of Listed Companies in Malaysia'. Journal of Trends and Development in Management Studies, Vol. 1 No. 2, pp.43-65.

Zabria, S. M., Ahmadb, K., \& Wahc, K. K. (2015). 'Corporate Governance Practices and Firm Performance: Evidence from Top 100 Public Listed Companies in Malaysia'. Procedia Economics and Finance, Vol. 35 No. 1, pp. 287 - 296. 
Table 1:

Variables Operational Definitions

\begin{tabular}{|c|c|c|}
\hline Variables & Acronym & Measurement \\
\hline \multicolumn{3}{|l|}{ Dependent Variables } \\
\hline Tobin's Q & TBQ & $\begin{array}{l}\text { The ratio of the book value of total assets minus the book } \\
\text { value of equity, plus the market value of equity to the book } \\
\text { value of assets, expressed as a percentage. }\end{array}$ \\
\hline Return on Assets & ROA & $\begin{array}{l}\text { Net Income divided by Total Assets expressed as a } \\
\text { percentage. }\end{array}$ \\
\hline Return on equity & ROE & $\begin{array}{l}\text { Net Income divided by shareholder's equity expressed as a } \\
\text { percentage. }\end{array}$ \\
\hline \multicolumn{3}{|l|}{ Independent variables } \\
\hline Board size & BSIZE & Measured by the number of members on the board. \\
\hline Board independence & BINDP & $\begin{array}{l}\text { Measured by the number of independent directors on the } \\
\text { board. }\end{array}$ \\
\hline Board meeting & BME & $\begin{array}{l}\text { Measured by the number of annual meetings held by the } \\
\text { board }\end{array}$ \\
\hline Audit Committee size & AUCSIZE & $\begin{array}{l}\text { Measured by the number of members of the Audit } \\
\text { Committee. }\end{array}$ \\
\hline Audit committee meeting & AUCME & $\begin{array}{l}\text { Measured by the number of annual meetings held by the } \\
\text { audit committee }\end{array}$ \\
\hline \multicolumn{3}{|l|}{ Control variables } \\
\hline Audit type & Big4 & $\begin{array}{l}\text { One if a company is audited by a Big Four audit firm } \\
\text { (PricewaterhouseCoopers, Deloitte \& Touche, Ernst \& } \\
\text { Young, and KPMG), } 0 \text { otherwise. }\end{array}$ \\
\hline Total assets & TA & The logarithm of the total assets in the year. \\
\hline Sector type & SEC & 1 If the company is from the financial sector, 0 otherwise. \\
\hline Leverage / Debt proportion & DOA & The percentage of total liabilities to total assets. \\
\hline
\end{tabular}


Table 2:

Summary descriptive statistics of all research variables for all 300 firm years

\begin{tabular}{lclll}
\hline Variable & Mean & Std. Deviation & Minimum & Maximum \\
\hline Dependent Variables & & & \\
\hline TBQ & 2.342 & 1.740 & -0.730 & 8.670 \\
ROA & 0.020 & 0.058 & -0.760 & 0.320 \\
ROE & 0.005 & 0.503 & -0.820 & 0.680 \\
\hline Independent Variables & & & \\
\hline BSIZE & 8.527 & 1.557 & 4.00 & 12.00 \\
BINDP & 4.317 & 1.556 & 3.00 & 11.00 \\
BME & 5.313 & 1.798 & 1.00 & 16.00 \\
AUCSIZE & 3.603 & 0.857 & 3.00 & 6.00 \\
AUCME & 5.590 & 1.917 & 1.00 & 13.00 \\
\hline Control Variables & & & 23.43 \\
\hline TOA & 19.689 & 0.911 & 17.63 & 0.985 \\
DOA & 0.413 & 0.376 & 0.008 & 1.00 \\
SEC & 0.500 & 0.508 & 0.00 & 0.00 \\
Big4 & 0.689 & 0.464 & 1.00 & \\
\hline Not Tab & & & & \\
\hline
\end{tabular}

Note: Table 1 completely defines all the variables employed in this study. 
Table 3:

Pearson and Spearman correlation matrices of the research variables for all 300 firm years

\begin{tabular}{lcccccccccccc}
\hline & TBQ & ROA & ROE & BSIZE & BINDP & BME & AUCSI & AUCME & TA & SEC & BIG4 & DOA \\
\hline TBQ & & .026 & .040 & $.446^{* *}$ & -.039 & $.177^{* *}$ & $.435^{* *}$ & -.020 & $-.370^{* *}$ & -.059 & $.365^{* *}$ & .004 \\
ROA & .026 & & $.858^{* *}$ & -.033 & .001 & .004 & .111 & .010 & -.019 & -.089 & .051 & -.020 \\
ROE & .040 & $.858^{* *}$ & & -.002 & -.003 & -.026 & .078 & .044 & .011 & -.024 & .113 & -.009 \\
BSIZE & $.446^{* *}$ & -.033 & -.002 & & $.316^{* *}$ & .103 & $.367^{* *}$ & .002 & -.065 & $.266^{* *}$ & $.430^{* *}$ & $.169^{* *}$ \\
BINDP & -.039 & .001 & -.003 & $.316^{* *}$ & & -.034 & -.023 & .018 & .017 & .105 & $-.137^{*}$ & -.026 \\
BME & $.177^{* *}$ & .004 & -.026 & .103 & -.034 & & $.348^{* *}$ & $.293^{* *}$ & .062 & $-.149^{* *}$ & .097 & -.082 \\
AUCSIZ & $.435^{* *}$ & .111 & .078 & $.367^{* *}$ & -.023 & $.348^{* *}$ & & .017 & -.092 & $-.175^{* *}$ & $.331^{* *}$ & -.106 \\
AUCME & -.020 & .010 & .044 & .002 & .018 & $.293^{* *}$ & .017 & & $.186^{* *}$ & .023 & .044 & .060 \\
TA & $-.370^{* *}$ & -.019 & .011 & -.065 & .017 & .062 & -.092 & $.186^{* *}$ & & $.261^{* *}$ & .028 & -.019 \\
SEC & -.059 & -.089 & -.024 & $.266^{* *}$ & .105 & $-.149^{* *}$ & $-.175^{* *}$ & .023 & $.261^{* *}$ & & $.183^{* *}$ & $.805^{* *}$ \\
BIG4 & $.365^{* *}$ & .051 & .113 & $.430^{* *}$ & $-.137^{*}$ & .097 & $.331^{* *}$ & .044 & .028 & $.183^{* *}$ & & $.180^{* *}$ \\
DOA & .004 & -.020 & -.009 & $.169^{* *}$ & -.026 & -.082 & -.106 & .060 & -.019 & $.805^{* *}$ & $.180^{* *}$ & \\
\hline
\end{tabular}

Notes: the bottom left half of the table shows the parametric correlation coefficients of Pearson, although the upper right half of the table shows the non-parametric correlation coefficients of Spearman. ${ }^{* *}$, * denote correlation is respectively significant at the levels $1 \%$, and $5 \%$. The variables are wholly defined in Table 1 . 
Table 4:

The relationship between CG and FV in Saudi Arabia

\begin{tabular}{|c|c|c|c|c|c|c|}
\hline MODELS & (1) & (2) & (3) & (4) & (5) & (6) \\
\hline VARIABLES & $\begin{array}{c}\text { Fixed-Effects } \\
\text { TBQ }\end{array}$ & $\begin{array}{c}\text { Fixed-Effects } \\
\text { ROA }\end{array}$ & $\begin{array}{c}\text { Fixed-Effects } \\
\text { ROE }\end{array}$ & $\begin{array}{c}\text { GMM } \\
\text { TBQ }\end{array}$ & $\begin{array}{l}\text { GMM } \\
\text { ROA }\end{array}$ & $\begin{array}{l}\text { GMM } \\
\text { ROE }\end{array}$ \\
\hline \multicolumn{7}{|c|}{ Corporate Governance Mechanisms (CGM) } \\
\hline BSIZE & $\begin{array}{l}1.223^{* *} \\
(0.562)\end{array}$ & $\begin{array}{l}-0.0347 \\
(0.0262)\end{array}$ & $\begin{array}{l}-0.270 \\
(0.213)\end{array}$ & $\begin{array}{c}23.433 * * * \\
(8.55)\end{array}$ & $\begin{array}{l}-0.219 \\
(0.346)\end{array}$ & $\begin{array}{l}-2.819 \\
(3.212)\end{array}$ \\
\hline BINDEP & $\begin{array}{l}-0.326^{*} \\
(0.195)\end{array}$ & $\begin{array}{l}-0.0121 \\
(0.0124)\end{array}$ & $\begin{array}{l}-0.0800 \\
(0.105)\end{array}$ & $\begin{array}{l}-3.623^{*} \\
(1.650)\end{array}$ & $\begin{array}{l}-0.0570 \\
(0.0656)\end{array}$ & $\begin{array}{l}-0.592 \\
(0.618)\end{array}$ \\
\hline BME & $\begin{array}{l}0.0874 \\
(0.170)\end{array}$ & $\begin{array}{l}-0.00259 \\
(0.0119)\end{array}$ & $\begin{array}{l}-0.111 \\
(0.103)\end{array}$ & $\begin{array}{l}-4.448 \\
(5.435)\end{array}$ & $\begin{array}{c}0.0278 \\
(0.0683)\end{array}$ & $\begin{array}{l}0.0357 \\
(0.510)\end{array}$ \\
\hline AUCME & $\begin{array}{c}0.289 * * \\
(0.141)\end{array}$ & $\begin{array}{c}0.0101 \\
(0.0101)\end{array}$ & $\begin{array}{c}0.120 \\
(0.0879)\end{array}$ & $\begin{array}{c}0.772 \\
(1.103)\end{array}$ & $\begin{array}{l}0.00255 \\
(0.0188)\end{array}$ & $\begin{array}{l}0.0925 \\
(0.172)\end{array}$ \\
\hline AUCSIZE & $\begin{array}{c}0.102 \\
(0.316) \\
\end{array}$ & $\begin{array}{l}0.0388 * \\
(0.0203) \\
\end{array}$ & $\begin{array}{r}0.242 \\
(0.173) \\
\end{array}$ & $\begin{array}{r}24.17 \\
(28.18) \\
\end{array}$ & $\begin{array}{r}-0.0722 \\
(0.394) \\
\end{array}$ & $\begin{array}{r}0.439 \\
(2.877) \\
\end{array}$ \\
\hline \multicolumn{7}{|l|}{ Controls } \\
\hline BIG4 & $\begin{array}{c}0.874 * * * \\
(0.143)\end{array}$ & $\begin{array}{c}0.00693 \\
(0.00950)\end{array}$ & $\begin{array}{c}0.146^{*} \\
(0.0815)\end{array}$ & $\begin{array}{l}-3.343 \\
(4.532)\end{array}$ & $\begin{array}{l}2.855^{*} \\
(1.490)\end{array}$ & $\begin{array}{l}2.628^{*} \\
(1.599)\end{array}$ \\
\hline SEC & $\begin{array}{c}-0.801^{* *} \\
(0.368)\end{array}$ & $\begin{array}{c}-0.811^{* *} \\
(0.375)\end{array}$ & $\begin{array}{c}-0.840^{* * *} \\
(0.180)\end{array}$ & $\begin{array}{c}1.834 \\
(3.293)\end{array}$ & $\begin{array}{l}-0.0135 \\
(0.0581)\end{array}$ & $\begin{array}{c}0.199 \\
(0.434)\end{array}$ \\
\hline DOA & $\begin{array}{l}-0.00157 \\
(0.0636)\end{array}$ & $\begin{array}{c}0.00437 \\
(0.00284)\end{array}$ & $\begin{array}{l}0.00767 \\
(0.0231)\end{array}$ & $\begin{array}{c}0.000184 \\
(0.187)\end{array}$ & $\begin{array}{c}0.00326 \\
(0.00376)\end{array}$ & $\begin{array}{l}-0.00725 \\
(0.0276)\end{array}$ \\
\hline TA & $\begin{array}{c}-0.0697 \\
(0.0854)\end{array}$ & $\begin{array}{c}-0.00112 \\
(0.00445) \\
\end{array}$ & $\begin{array}{r}-0.00145 \\
(0.0371) \\
\end{array}$ & $\begin{array}{c}-0.258 \\
(0.502)\end{array}$ & $\begin{array}{c}-0.683 * * * \\
(0.0928) \\
\end{array}$ & $\begin{array}{c}-0.675 * * * \\
(0.0971) \\
\end{array}$ \\
\hline Constant & $\begin{array}{c}1.537 * * * \\
(2.014)\end{array}$ & $\begin{array}{l}0.0326 \\
(0.102)\end{array}$ & $\begin{array}{c}0.102 \\
(0.843)\end{array}$ & $\begin{array}{l}-20.80 \\
(33.55)\end{array}$ & $\begin{array}{c}0.532 \\
(0.517)\end{array}$ & $\begin{array}{c}5.179 \\
(4.820)\end{array}$ \\
\hline F-Value & $12.964 * * *$ & $5.657 * * *$ & $5.657 * * *$ & $3.928 * *$ & $6.012^{* * *}$ & $7.241 * * *$ \\
\hline Adjusted $\mathrm{R}^{2}$ & 0.34 & 0.23 & 0.22 & 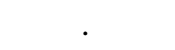 & . & . \\
\hline Observations & 300 & 300 & 300 & 297 & 297 & 297 \\
\hline
\end{tabular}

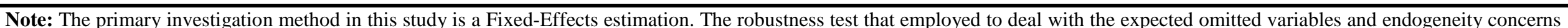
is a GMM model, respectively. The variables are entirely defined in Table 1.

Standard errors in parentheses

*** $\mathrm{p}<0.01, * * \mathrm{p}<0.05, * \mathrm{p}<0.1$ 